Copyright $(\odot 2018$ by the Kalmyk Scientific Center of the Russian Academy of Sciences

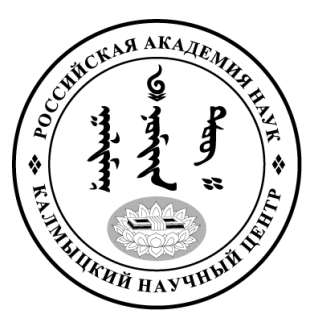

Published in the Russian Federation

Oriental Studies (Previous Name: Bulletin of the Kalmyk Institute for

Humanities of the Russian Academy of Sciences)

Has been issued as a journal since 2008

ISSN: 2619-0990; E-ISSN: 2619-1008

Vol. 39, Is. 5, pp. 132-144, 2018

DOI 10.22162/2619-0990-2018-39-5-132-144

Journal homepage: https://kigiran.elpub.ru

УДК 811.512 .37 (Калм)

\title{
К проблеме семантики некоторых лексических единиц, обозначающих «плеть» (на материале эпоса «Джангар»)
}

Евгений Владимирович Бембеев ${ }^{l}$

${ }^{1}$ кандидат филологических наук, старший научный сотрудник, отдел монгольской филологии, Калмыцкий научный центр РАН (358000, Россия, г. Элиста, ул. им. И. К. Илишкина, д. 8). ORCID: 0000-0001-9936-221X. E-mail: galdma@yandex.ru

\section{Аннотация}

Введение. Анализ семантической структуры слова, установление или восстановление его значения в эпическом произведении является сложной задачей, которая обусловлена хронологической неоднородностью разных версий эпоса, утратой или неясностью семантики слова, переходом его из активного бытования в пассивный запас или изменением его формы.

Цель. Провести анализ семантической структуры лексем (тоориг/товриз, елдң), обозначающих оружие в калмыцком героическом эпосе «Джангар».

Meтоды. Автоматический разбор корпуса текстов позволяет оперировать большим объемом информации, поэтому контекстологический метод является одним из основных методов анализа, позволяющий установить типовую сочетаемость для каждой лексической единицы. Помимо этого используются анализ словарных дефиниций, валентностный анализ, позволяющие выявить особенности семантической дефиниции в лексикографических источниках, грамматические и акцентологические признаки искомых единиц.

Результаты. Проведенный анализ позволяет не только установить или восстановить значение отдельной лексемы, но и в некоторых случаях выявить различия в семантике одной и той же лексемы. Эти различия объясняются разностью контекстов употребления, которые, в свою очередь, обусловлены стадиальными особенностями конкретной версии эпоса, спецификой исполнительской школы, воспитавшей сказителя, а также временем письменной фиксации устного исполнения эпического текста.

Bblводы. Верным является употребление слова товриг 'плеть с утолщением на конце, плетение которого похоже на нераскрывшуюся сосновую шишку' - ‘боевая плеть'. Это слово принадлежит к общему тюрко-монгольскому лексическому фонду народов Саяно-Алтайского нагорья. Форму тоориц (дважды у Д. Шавалиева) можно также считать авторской особенностью или же искажением. Вместе с тем эта форма могла появиться в результате неточной письменной фиксации устного исполнения.

Лексема елдң встречается 52 раза в разных версиях эпоса в различных контекстах. Ее значения разнятся в зависимости от стадиальной принадлежности версии и локализации исполнительской школы. На материале эпоса лексема елдң применяется в прямом и переносных значениях и обнаруживает широкий семантический спектр: 1) 'нагайка' как вид плети - маля; 2) 'дружинник’, ‘защитник’; 3) ‘благородный, праздный’; 4) 'неудержимый’, 'непоседливый’, 'беспокойный', 'суетливый' Так, в ранней, Малодербетовской, версии фиксируются значения: 1) 'нагайка' как вид плети - маля; 2) елдң широко применяется как 'богатырь', конкретно 'нагаечник'. В значении 3) слово переведено по контексту как 'благородный, празднующий' о заглавном герое эпоса, Джангаре, к которому съезжаются богатыри на праздник Цаган Сар. 
В значении 4) 'неудержимый’ елдң применено к любимому народом эпическому герою и подчеркивает стремительность, порывистость богатыря Хонгора.

В более поздних версиях эпоса для лексемы елдң фиксируются следующие значения 1) 'нагайка' как вид плети — маля; 2) не употребляется; 3) не употребляется; 4) в переносном смысле применяется для отрицательной характеристики 'своенравного, беспокойного' человека. Следовательно, семантический спектр лексемы елдң сужается и обедняется на пути от ранней, Малодербетовской, к поздним версиям эпоса.

Ключевые слова: калмыцкий язык, эпос «Джангар», толковый словарь, плеть, значения, лексема, семантика, эпос «Джангар», корпус

\section{1. Введение}

В процессе создания Толкового словаря языка калмыцкого героического эпоса «Джангар» авторы сталкиваются с лексемами, значение которых не ясно. Понимание эпического текста определяется в значительной мере знанием особенностей его лексического состава. Это справедливо отмечает Э. Ч. Бардаев, считая, что для современных носителей калмыцкого языка семантика большинства слов-архаизмов стала непонятной, а для некоторых лексем и вовсе утерянной. Поэтому перед лингвистами встает задача по восстановлению значения этих лексем, т. е. «найти их смысл или, по крайней мере, близкое к нему значение» [Бардаев 1980: 393].

Героический эпос «Джангар» занимает в культуре ойратов и калмыков особое место. Эпические тексты хранят в себе свидетельства архаичности. В первую очередь древнее самосознание и мироощущение кочевого народа отражают лексические элементы.

В данной работе предпринимается попытка восстановления значения лексических единиц по таким признакам, как: сочетаемость слова, его грамматические и акцентологические признаки, строение слова. Опыт реконструкции значений лексических единиц на материале монгольских языков, а также на материале эпоса «Джангар» проведен в ряде работ А. В. Дыбо [Дыбо 2015: 209-254], Г. Ц. Пюрбеева [Пюрбеев 2011; 2015], В. В. Кукановой [Куканова 2016а; 2016б].

2. Материалы и методы исследования Материалом исследования служат 28 текстов разновременных записей калмыцкого героического эпоса «Джангар» ${ }^{1}$, которые объединены в репертуарные циклы: Малодербетовский цикл (3 песни), Багацохуровский цикл (3 песни), репертуар

1 В КалмНЦ РАН создается «Свод калмыцкого фольклора», который включает в себя репрезентативные песни эпоса «Джангар».
Ээлян Овла (10 песен, магтал), Мукебюн Басангов (6 песен), Дава Шавалиев (4 песни, магтал), а также представлены отдельными песнями: Насанка Балдыров (1 песня), Бадма Обушинов (1 песня).

Лексическое значение слова является многомерным явлением и включает в себя ряд разноплановых компонентов. Поэтому при установлении семантики слова исходят из контекстуального окружения или же опираются на семантические определения, которые приводятся в лексикографических источниках. Автоматический разбор корпуса текстов эпоса «Джангар» проведен посредством морфологического анализатоpa «TextAnalyzer», который существенно облегчает работу по обнаружению разного рода языковых единиц в письменном тексте, дает полную информацию о частотности употребления этих единиц, их ранжировании в текстах, сочетаемости с другими единицами и т. п. [Бембеев, Куканова, Каджиев 2014].

Автоматический разбор корпуса текстов позволяет также оперировать большим объемом информации, поэтому контекстологический метод является одним из основных методов анализа. Он заключается в том, что в процессе обобщения широкого иллюстративного материала, для каждой лексической единицы может быть установлена типовая сочетаемость. Она может быть представлена в виде обобщенной характеристики тех позиций, которые чаще всего реализуются в контексте слова.

Для выявления и реконструкции значений лексических единиц использованы различные лексикографические источники: Монгольско-русско-французский словарь [МРФС 1844-1849], Монгольско-русский словарь [МРС 1893-1895], «Калмыцко-русский словарь» [КРС 1911], Калмыцко-немецкий словарь [KW 1935], «Опыт лингвистического исследования эпоса «Джангар» [ОЛИЭД 1976], «Калмыцко-русский сло- 
варь» [КРС 1977], «Словарь языка ойратов Синьцзяна» [СЯОС 2001], «Большой академический монгольско-русский словарь» [БАМРС 2001; 2002], «Ойрат-монгольский словарь» [ОМС 2006], «Толковый словарь традиционного быта калмыков» [ТСТБК 2016] и др.

\section{3. Восстановление значений лексических единиц}

В текстах эпоса «Джангар» встречаются две лексемы: тоориз (2) ${ }^{1}$ и товриз (4), которые означают один и тот же предмет - одну из разновидностей маля 'боевая плеть'. Лексема тооричг выявлена нами только в

Таблица 1. Употребление лексемы тоориг / товриз в текстах эпоса «Джангар»

\begin{tabular}{|c|c|c|}
\hline 1. & $\begin{array}{c}\text { Әәрстин елдң хар тоорицг атхад... } \\
\text { [ШД: I] }\end{array}$ & Взял он [в руку] рубчатую богатырскую черную плеть \\
\hline 2. & $\begin{array}{l}\text { Әәрстин елдң товрццг маляһан } \\
\text { Атхад һарч ирәд... }\end{array}$ & $\begin{array}{l}\text { Взяв в руку рубчатую богатырскую плеть-маля, } \\
\text { Вышел он }\end{array}$ \\
\hline 3. & $\begin{array}{l}\text { Әәрстин елдң хар тоорицг } \\
\text { Барун һартан атхад... [ШД: III] }\end{array}$ & $\begin{array}{l}\text { Рубчатую богатырскую черную плеть } \\
\text { Сжав в правой руке... }\end{array}$ \\
\hline 4. & $\begin{array}{l}\text { Әәрстин елдң хар товризиг } \\
\text { Атхад, мордв. }\end{array}$ & $\begin{array}{l}\text { Рубчатую богатырскую черную плеть-маля, } \\
\text { Сжав [в руке], вскочил в седло. }\end{array}$ \\
\hline 5. & $\begin{array}{l}\text { Әәрстин хар товричг } \\
\text { Альхнь тасртл, гөвдлдв. [МД:II] }\end{array}$ & $\begin{array}{l}\text { Рубчатой черной плети } \\
\text { [Плетения] наладонной петли пока не порвались, } \\
\text { бились они. }\end{array}$ \\
\hline 6. & $\begin{array}{l}\text { Әәрстә хар товричг } \\
\text { Бәәдг болна. }\end{array}$ & $\begin{array}{l}\text { Черную плеть-товорцак } \\
\text { Видит [он]. }\end{array}$ \\
\hline
\end{tabular}

текстах песен Давы Шавалиева, причем джангарчи параллельно употребляет и слово товриг. В контексте данные лексемы сопровождаются прилагательными: дәрстин елдң хар, дәрстин елдң, әәрстә хар.

Примеры лексем тоориг и товриц позволяют наблюдать процесс образования долгих гласных из комплекса ГСГ (гласный + согласный + гласный). Согласно анализу академика Б. Я. Владимирцова, в монгольских языках этот процесс проходил следующим образом. В раннемонгольском языке интервокальные $\gamma \sim \mathrm{g}$, а ранее и ${ }^{*} w$, «начали ослабляться, становясь более широкими и вокализируясь; благодаря этому $\gamma \sim \mathrm{g}$ или исчезли вовсе, или заменились билабиальным спирантом $w$ в тех случаях, когда один из гласных, чаще всего второй, был $u \sim \ddot{u}$, и спирантом $y$ тогда, когда один из гласных, первый, был $\ddot{i}>i \sim i \gg$ [Владимирцов 1989: 215-216].

В дальнейшем началось ослабление и полное исчезновение спирантов $w$ и $y$, а затем два гласных слились в один долгий, который мы имеем в настоящее время. Вместе с тем Б. Я. Владимирцов отмечает: «... в одних наречиях получился долгий гласный, в других диалектах монгольских в тех же случаях долгого гласного не случилось, а сохранился заднеязычный шумный, наслед- ник $\gamma \sim g$, или *w» [Владимирцов 1989: 235]. Для нас особенно важен пример из общего тюрко-монгольского лексического фонда, приводимый ученым, монг.-письм. toүurс̌aq 'волосы, собранные чубом, цветочная чашечка, шишка хвойного дерева, шапка конусообразной формы', халx. то̄рцо̌к 'шапкаторцык' | Захач. тош, ц $^{\circ}$ к 'шишка, нагайка с завитым концом, узел на конце плети (ср. тюрк.: Тел., Тор. тобырчык 'нагайка с завитым концом, узел на конце плети' <* toүurčaq $\sim<$ toburčaq [Владимирцов 1989: 205].

Согласно лексикографическим источникам, в старописьменном монгольском языке слово toүurčaq обозначало предмет шишкообразной формы и переводилось как 'сердечко цветка, цветная чашечка; волосы, собранные чубом, прическа; шишка хвойного дерева; головной убор' [Ковалевский 1844: 1817 ; Голстунский 1853: 130; Владимирцов 1989: 205]. ${ }^{1}$

В дальнейшем, в ходе развития долготного комплекса ГСГ на почве различных монгольских наречий образовались две лексемы: I. тоориз [tōrcaq], которое обозначает '1) женская шапочка, украшенная кисточкой в форме шишки; 2) цветочная чашечка', и II. товриз [toburčoq] '1) шишка, желудь; 2) плеть, нагайка (короткая ременная плеть)'.

\footnotetext{
${ }^{1}$ Количество употреблений в тексте эпоса.
} 


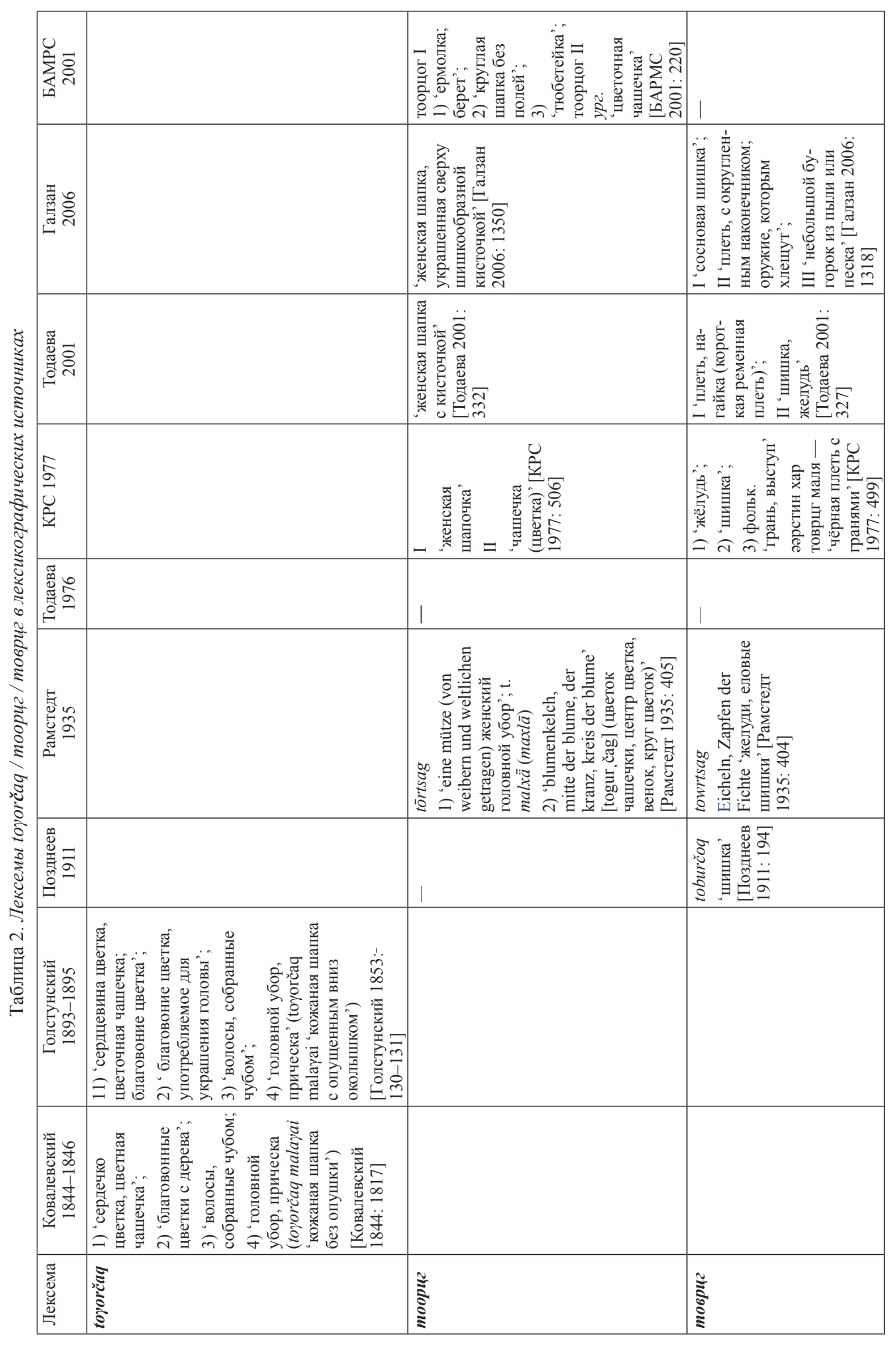


Oriental Studies, 2018, Vol. 39, Is. 5

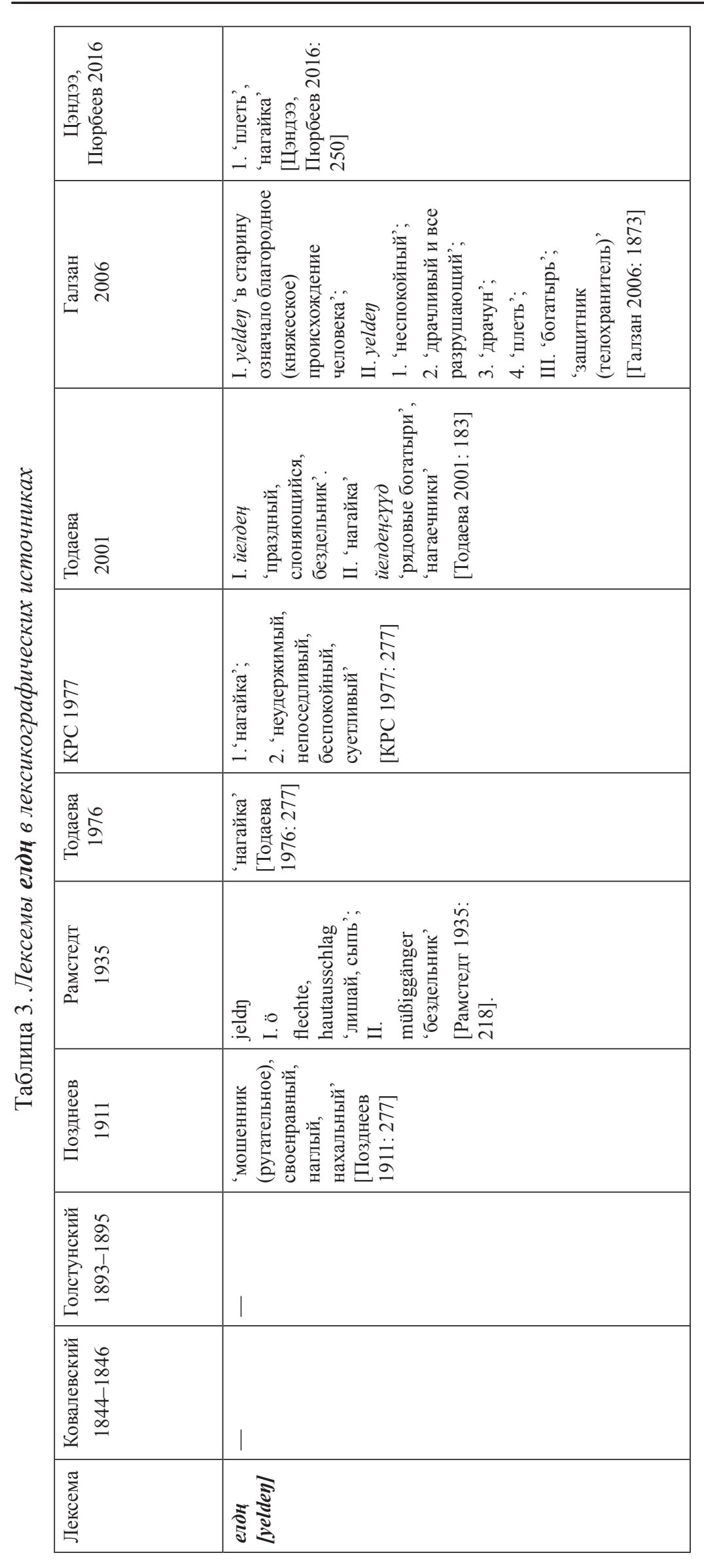


Причем лексема товрия в значении 'нагайка с завитым концом, узел на конце плети' обнаруживается только на материале западно-монгольских диалектов (захач. тош,рцํ 'шишка, нагайка с завитым концом, узел на конце плети' [Владимирцов 1989: 205], oйрат.-торг. 'плеть, с округленным наконечником; оружие, которым хлещут' [Галзан 2006: 1318]. На примере слова toүurčaq мы можем наблюдать два фонетических явления: развитие долгого гласного [о̄] из

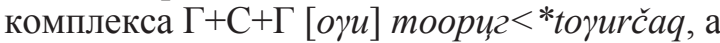
также явление, которое Б. Я. Владимирцов определяет как «отсталая фонетическая эволюция», когда на месте долготного комплекса ГСГ «долгого гласного не получилось, а сохранился заднеязычный шумный, наслед-

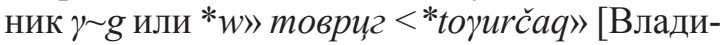
мирцов 1989: 234-235].

Есть множество примеров, которые показывают неоднородность развития долготного комплекса ГСГ на материале различных монгольских языков: degel debel 'шуба' > халх.-м. дээл|калм. девл| бур. дэгэл; egem 'плечо, ключица' > халх.-м. эгэм | калм. ээм | бур. ээм.

В своей работе А. В. Дыбо отмечает, что лексема товризг в значении «плеть» встречается только на материале калмыцкого языка и языке ойратов Синьцзяня и Монголии, что говорит о заимствованном характере данного слова из тюркских языков [Дыбо 2015: 241-242]. В тюркских языках данная лексема используется в значении ‘нагайка, плеть': Тюрк. Тел., Тор. тобырчык 'нагайка с завитым концом, узел на конце

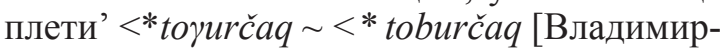
цов 1989: 205]», Хак. табырчын, тобырчых ‘фольк. нагайка' [ХРС 1953: 229]. Встречающееся в тувинском эпосе «Хунан-Кара» слово довурзак переводчик комментирует как соответствующее ойрат-калмыцкому товрич [Тувинские героические сказания 1997: 535-536].

Выявляя семантику лексемы товризг в калмыцком языке, известный джангаровед и лексикограф А. Ш. Кичиков отмечает, что богатырский товриц - это плеть (маля) $<\ldots>$. Свое наименование маля-товричг она получила из-за утолщения на конце, сплетенного наподобие сосновой семенной шишки-товрияг. «Такая плеть с шишкойтовризг на конце в бою была оружием: если опытный боец бичевал плетью [, грани плетения которой подобны] зубам бычка-двухлетки, [усиленной] шишкой-товризг на кон- це, врагу удержаться на коне было трудно» [Кичиков 2017: 116-117].

Историк и этнограф У. Э. Эрдниев писал, что калмыцкая плеть, изготовленная «из тонких ремешков вокруг ремневого стержня, круглая в сечении» отличается выдающейся прочностью и изящностью отделки [Эрдниев 1985: 100-101].

Таким образом, рассматривая вопрос этимологии лексемы товризг, необходимо отметить, что она восходит к toүurčaq и обозначает предмет шишкообразной формы 'сердечко цветка, цветная чашечка; волосы, собранные чубом, прическа; шишка хвойного дерева; головной убор'. Во всех монгольских языках слово toүurčaq в ходе развития долготного комплекса ГСГ дало форму тоориз [tōrcaq], которое обозначает '1) женская шапочка, украшенная кисточкой в форме шишки; 2) цветочная чашечка'. В западно-монгольских диалектах (калмыцком и ойратском), помимо данной лексемы, встречается форма товризг [toburčoq] '1) шишка, желудь; 2) плеть, нагайка (короткая ременная плеть)', которая, вероятнее всего, является заимствованием из тюркских языков. В таком случае в текстах песен эпоса «Джангар» в значении 'плеть или нагайка' верным будет употребление формы товризг. Форму тооризг, которая встречается дважды в репертуаре Давы Шавалиева, причем параллельно с формой товрицг, можно считать авторской особенностью или авторским искажением. Но, кроме того, здесь может иметь место результат неправильной письменной фиксации устного исполнения.

\section{2. Лексема елдң (52)}

Контекст употребления слова товриза/ тоориг включает в себя следующие словосочетания: дәрстин елдң хар тоориц мәләһән, әәрстин елдн̧ товричг маляһан, әәрстин елдң хар товригси, дәрстин хар товричг, әәрстә хар товричг. В этих примерах слово товриг предваряется эпитетами в форме прилагательного хар 'черный', существительного/прилагательного елдң 'плеть, нагайка', субстантивированного прилагательного әәрстин/аәрстә 'рельефная (поверхность), огрубелая (о коже рук, ног)', которые здесь усиливают качественные характеристики 'плети'. В рассматриваемом контексте обращает на себя внимание употребление слова елдн..

Этимология данной лексемы неизвестна. Известный алтаист Г. Рамстедт соотно- 
сит jeldy со словом jaldy '(schimpfend) eklig, vermodert, entblösst - отвращение, гниение, обнажение'. Автор также считает это слово синонимом лексеме хūwxä | xūwxā [Рaмстедт 1935: 214]. В современном калмыцком хувха переводится как 'плохой, скверный' [КРС 1977: 605].

В словарях современного калмыцкого языка лексема елдң означает: 1) один из видов боевой плети маля - 'нагайка' [Тодаева 1976: 277; КРС 1977: 222]; 2) употребляется в качестве прилагательного при характеристике непоседливого, беспокойного человека; бездельника [КРС 1977: 222].

В словарях ойратов Синьцзян-Уйгурского автономного района КНР лексема йелдең употребляется в следующих значе- ниях: I. ycm. 'благородное (княжеское) происхождение (о человеке)'; II. 1) 'непоседливый, беспокойный человек'; 2) 'дебошир, который все ломает’; 3 ) 'драчун'; 4) 'плеть'; III. 'богатырь'; 'защитник (телохранитель)' [Галзан 2006: 1873]. Б. Х. Тодаева приводит следующие значения лексемы йелдең:: I. 'праздный, слоняющийся; бездельник'; II. 'нагайка', а также множественное число этой лексемы йелденцүүд переводит как 4) 'рядовые богатыри', 'нагаечники' [Тодаева 2001: 183]. Таким образом, значения данной лексемы у каждого автора существенно разнятся. В таблице 4 приводятся примеры и контексты употребления лексемы елдң в текстах калмыцкого эпоса «Джангар».

Таблища 4. Употребление лексемы yeldey елдң в текстах эпоса «Джангар»

\begin{tabular}{|c|c|c|}
\hline 1. & $\begin{array}{l}\text { Елдңзгүдин һурвн миңһн бийәр } \\
\text { Елдң богддан цаһа бәрхәр } \\
\text { Шигәд мордв. } \quad \text { [МД: III] }\end{array}$ & $\begin{array}{l}\text { С ним три тысячи богатырей (нагаечников) } \\
\text { благородному богдо своему Цаган [-подношения] } \\
\text { преподнести } \\
\text { Плотным строем отправились. }\end{array}$ \\
\hline 2. & $\begin{array}{l}\text { Арг Улан Хоңһрин } \\
\text { Әмн дундан хадһлгсн } \\
\text { Елдңзудин һорвн миңһн баатр } \\
\text { Елдң Хоңһран дахад мордв. } \\
\text { [Мд:II] }\end{array}$ & 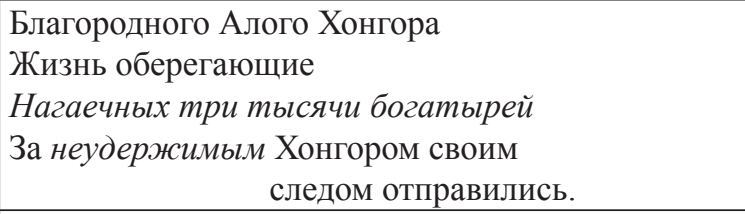 \\
\hline 3. & $\begin{array}{l}\text { Әәрстин елдң хар тоорцг } \\
\text { Барун һартан атхад... [ШД: III] }\end{array}$ & $\begin{array}{l}\text { Сжал он в правой руке } \\
\text { Рубчатую богатырскую черную плеть... }\end{array}$ \\
\hline & $\begin{array}{l}\text { Әәрстин хар елднцгән чирәд, } \\
\text { Киитн хар нүдәрн дөрвн талан } \\
\text { хәләв. [ЭО: Х] }\end{array}$ & $\begin{array}{r}\text { И черную рубчатую плеть за собой } \\
\text { волоча, } \\
\text { Холодным [взором] черных глаз вокруг } \\
\text { посмотрел. }\end{array}$ \\
\hline 4. & $\begin{array}{l}\text { Сорнзг дала гидг даладан } \\
\text { Йирн йисн елдң маңһс хаани } \\
\text { көвүдиг } \\
\text { Дөчн йисн хонгар засглж хайв. } \\
\text { [БМ: I] }\end{array}$ & $\begin{array}{l}\text { Девяносто девять своенравных сыновей } \\
\text { Мангас-хана } \\
\text { На сорок девять суток } \\
\text { Бросил он в океан Сорынзыг. }\end{array}$ \\
\hline
\end{tabular}

Анализ показывает, что в текстах эпоса «Джангар» лексема елдң выявляется 52 раза и употребляется:

1) в значении 'боевая плеть', 'нагайка' слово елдң употреблено 27 раз и встречается в текстах песен Ээлян Овла, Мукёбюна Басангова, Давы Шавалиева. В Толковом словаре традиционного быта ойратов Монголии и калмыков елдң поясняется как булhap cyриг кесг давхрлад гүрсн бүдүн маля '(толстая плеть, сплетенная из юфтевых ремешков) плеть, нагайка' [Цэндээ, Пюрбеев 2016: 250];

2) в значениях 'богатырь', 'защитник', 'нагаечник'. Примечательно, что в данном значении слово елдң употреблено 19 раз и встречается только в Малодербетовской версии, которая является одной из самых ранних записанных версий эпоса «Джангар» и отличается многоплановой по своей наполненности эпической архаикой [Кичиков 1997: 178, 206-214];

3) в переносном значении 'своенравный', 'наглый', 'неудержимый', 'непоседливый', 'драчливый' слово используется для характеристики отрицательного персонажа в эпосе «Джангар» - 6 раз в репертуаре Мукебюна Басангова, где оно, например, употреблено в контексте «Йирн йисн елдң мацһс хаани көвүд...»- 'Девяносто девять своенравных сыновей Мангас-хана...’. 
Вопрос происхождения данной лексемы весьма спорный. А. В. Дыбо отмечает, что лексема елдң входит в состав собственно-ойратских слов и не встречается на материале других монгольских языков. Автор предполагает, что елдң по происхождению имя собственное [Дыбо 2015: 241].

Следуя важнейшему положению материалистического языкознания, которое заключается в том, что «понятия формируются и развиваются в сознании человека под воздействием многообразных явлений окружающего нас мира» [Будагов 2003: 93], предполагаем, что первое значение данной лексемы елдң - 'боевая плеть', 'нагайка'. В этом значение оно наиболее употребительно в тексте эпоса. Как известно, исторически развиваясь, многие лексемы языка приобретают новые сложные и отвлеченные понятия, которые далеко уходят от первоначального значения. Как справедливо отмечает Р. А. Будагов «развитие мышления приводит к тому, что у человека возникает настоятельная потребность обращаться не только к конкретным, но и отвлеченным словам и понятиям» [Будагов 2003: 90].

Поэтому, как нам представляется, значение лексемы елдң 'боевая плеть', 'нагайка' со временем трансформируется в понятие 'нагаечник', 'богатырь', 'защитник'. Необходимо подчеркнуть, что в данном значении лексема елдң фиксируется в материале самой ранней из записанных версий эпоса
«Джангар», а также оно коррелирует с таким же значением в материале языка ойратов СУАР КНР. В связи с тем, что в монгольских языках имена существительные и прилагательные тесно связаны и не имеют четких границ между собой, то лексема елдњ, употребляясь при именах существительных, выражает качество или признак предмета. Например, в применении к любимому герою калмыцкого эпоса, богатырю Хонгору, подчеркивает его стремительность, порывистость: Елдң Хоңһ $p$ (в Малодербетовской версии) - 'неудержимый Хонгор'. В более поздних версиях эпоса лексема елдң в значении 'дружинник', 'защитник' не употребляется, обозначая вид боевой плети маля.

В современном калмыцком языке лексема елдң выступает в двух значениях 1) плеть и 2) перен. непоседливый, беспокойный, своенравный человек (в смысле «мечется, как плеть»).

Историческое движение значений лексемы елдң можно выразить следующей схемой (рис. 1).

Анализ текстов эпоса «Джангар» показывает, что в своем историческом развитии лексема елдң отражала не только конкретные, но и отвлеченные понятия. В свою очередь носители новых значений, постепенно вступая в новые языковые ряды, в новые отношения, способствовали тому, что в некоторых случаях утрачивалось и забывалось предыдущее значение слова. Таким обра-

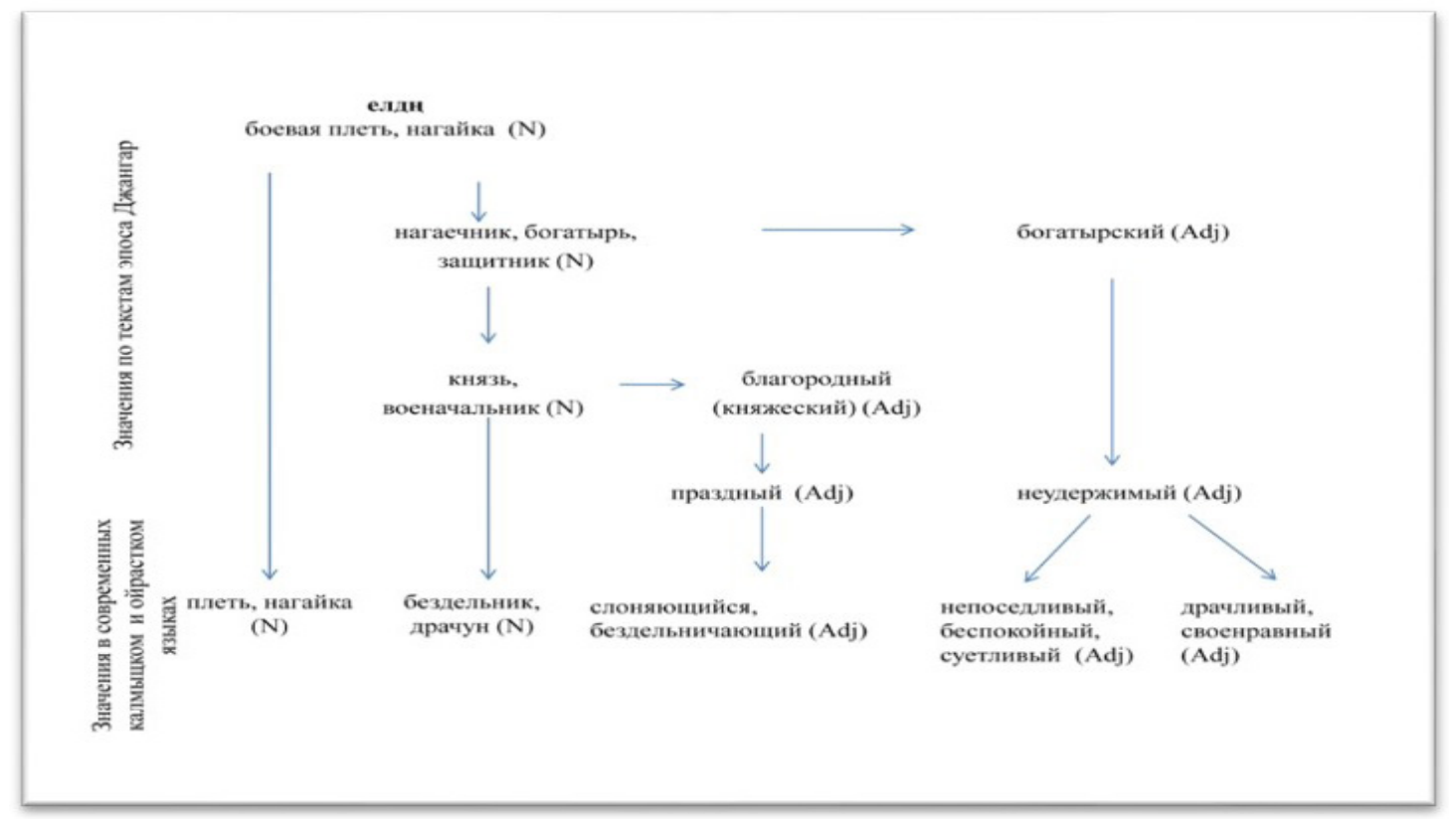

Рис. 1. Схема исторического развития лексемы елдң 
зом, можно отметить, что на пути от ранней, Малодербетовской, версии к более поздним версиям калмыцкого героического эпоса «Джангар» семантический спектр слова елдң сужается, а положительная семантика новых образований нередко имеет негативную коннотацию.

\section{4. Выводы}

Представленный в настоящей работе анализ семантической структуры лексем тооризг/товризг и елдң в калмыцком героическом эпосе «Джангар» позволяет сформулировать следующие выводы.

Верным является употребление слова товрич 'плеть с утолщением на конце, плетение которого похоже на нераскрывшуюся сосновую шишку' - 'боевая плеть'. Это слово принадлежит к общему тюрко-монгольскому лексическому фонду народов Саяно-Алтайского нагорья. Форму тоориц (дважды у Д. Шавалиева) можно также считать авторской особенностью или же искажением. Вместе с тем эта форма могла появиться в результате неточной письменной фиксации устного исполнения.

Лексема елдң встречается 52 раза в разных версиях эпоса в различных контекстах. Ее значения разнятся в зависимости от стадиальной принадлежности версии и локализации исполнительской школы. На материале эпоса лексема елдң применяется в прямом и переносных значениях и обнаруживает широкий семантический спектр: 1) 'нагайка' как вид плети - маля; 2) 'дружинник', 'защитник'; 3) 'благородный, праздный'; 4) 'неудержимый', 'непоседливый', 'беспокойный', 'суетливый'. Так, в ранней, Малодербетовской, версии фиксируются значения: 1) 'нагайка' как вид плети — маля; 2) елднз широко применяется как 'богатырь, конкретно — 'нагаечник'. В значении 3) слово переведено по контексту как 'благородный, празднующий' - о заглавном герое эпоса, Джангаре, к которому съезжаются богатыри на праздник Цаган Cap. В значении 4) 'неудержимый' елдң применено к любимому народом эпическому герою и подчеркивает стремительность, порывистость богатыря Хонгора.

В более поздних версиях эпоса для лексемы елдң фиксируются следующие значения 1) 'нагайка' как вид плети - маля; 2) не употребляется; 3) не употребляется; 4) в переносном смысле применяется для отрицательной характеристики 'своенравного, беспокойного' человека. Следовательно, семантический спектр лексемы елдң сужается и обедняется на пути от ранней, Малодербетовской, к поздним версиям эпоса.

Таким образом, анализ семантической структуры слова, установление или восстановление его значения в эпическом произведении является задачей, сложность которой обусловлена стадиальной принадлежностью эпического текста, утратой или неясностью семантики слова, переходом его из активного бытования в пассивный запас или изменением его формы. Решение подобной задачи требует скрупулезного анализа лексических единиц с учетом контекстуального окружения и сочетаемости слов, с опорой на семантические дефиниции в лексикографических источниках, с выявлением грамматических и акцентологических признаков искомых единиц, а также хронологических данных и локализации записей эпических текстов.

\section{ИСТОЧНИКИ / SOURCES \\ Малодербетовский цикл}

[МД:II] Күрл Эрднь Маңһс хааг богд Жаңһр дөрәцүлгсн бөлг.

[МД: III] Догшн Шар Гүргү Маңһс хааг Дуут Улан Шовшур дөрәцүлгсн бөлг.

\section{Багацохуровский цикл}

[БЦ: III] Догшн Замбл хаана һалзу долан бодңгиг Аср Улан Хоңһр Күнд һарта Савр хойр дөрәцүлгсн бөлг.

\section{Цикл песен из репертуара Ээлян Овла}

[ЭО: III] Баатр Хар Жилһн хаанла бәәр бәрлдгсн бөлг.

[ЭО: Х] Алтн Чееж Жаңһр хойрин бәәр бәрлдгсн бөлг.

\section{Цикл песен из репертуара Мукёбюна Басангова}

[БМ: I] Жаңһрин бийиннь түрүн төрән авгсн бөлг.

Цикл песен из репертуара Давы Шавалиева

[ШД: I] Арнзлын хурдн Зеердиг хулха авсна туск бөлг.

[ШД: II] Азг Улан Хоңһрин гер авлһна бөлг.

[ШД: III] Ке шар-цоохр мөртә Кермин көвүн Моңхуляла дәәллдгсн бөлг.

[ШД: IV] Оцл Дамбан көк һалзн күлгтә Азг Улан Хоңһр нисдг алг мөртә Арл Манз хааг даргсн бөлг.

[ШД: ЖМ] Жаңһрин магтал. 
Песня из репертуара Бадмы Обушинова

[ОБ: I] Баатр Улан Хоңһр Авлңһ хаанла бәәр бәрлдгсн бөлг.

\section{Список сокращений}

букв. - буквальный перевод

бур. - бурятский

захач. - захчинский

калм. - калмыцкий

халх.-м. - халха-монгольский

монг. - монгольский

монг.-письм. - монгольский письменный

ойр. - ойратский

ойр.-торг. - ойратский-торгутский

тел. - телеутский

тюрк. - тюркский

хак. - хакасский

халх. - халхаский

ПМА - Полевые материалы автора.

\section{ЛИТЕРАТУРA / REFERENCES}

KW 1935 - Ramstedt G.J. Kalmükisches Wörterbuch. Helsinki: Suomalais-Ugrilainen Seura, 1935. 592 s. [Ramstedt G. J. A dictionary of the Kalmyk language. Helsinki: Finno-Ugric Society, 1935. 592 s. (In Germ.)]

Бардаев 1980 - Бардаев Э. Ч. Некоторые вопросы изучения лексики «Джангар» // «Джангар» и проблемы эпического творчества тюрко-монгольских народов. Мат-лы Всесоюз. науч. конф. (г. Элиста, 17-19 мая 1978 г.). М.: Наука, 1980. С. 390-395. [Bardaev E. Ch. The Jangar epic: some issues of lexical studies. «Dzhangar» i problemy epicheskogo tvorchestva tyurko-mongol'skikh narodov. Conf. proc. (Elista, 17-19 May 1978). Moscow: Nauka, 1980. Pp. 390-395. (In Rus.)]

БАРМС 2001-2002 - Большой академический монгольско-русский словарь в 4-х томах / ред. А. Лувсандэндэв, Ц. Цэдэндамба, Г. Ц. Пюрбеев. М.: Academia, 2001-2002. Т. I. 502 c.; T. II. 536 c.; T. III. 440 c.; T. IV. 532 c. [Bol'shoy akademicheskiy mongol'sko-russkiy slovar' [Great Academic Mongolian-Russian Dictionary]. In 4 vol. A. Luvsandendev, Ts. Tsedendamba, G. Ts. Pyurbeev (eds.). Moscow: Academia, 2001-2002. Vol. 1, 502 p.; vol. 2, 536 p.; vol. 3, 440 p.; vol. 4, 532 p. (In Mong. and Rus.)]

Бембеев, Куканова, Каджиев 2014 - Бембеев Е. В., Куканова В. В., Каджиев А. Ю. Частотный словарь современного калмыцкого языка: правила анализа текстового материала // Вестник Калмыцкого института гуманитарных исследований РАН. 2014. № 3. C. 128-141. [Bembeev E. V., Kukanova V. V., Kadzhiev A. Yu. Frequency dictionary of modern Kalmyk Language: rules of analysis of text material. Vestnik Kalmytskogo instituta gumanitarnykh issledovaniy RAN (Bulletin of the Kalmyk Institute for Humanities of the RAS). 2014. No. 3. Pp. 128-141. (In Rus.)]

Будагов 2003 - Будагов Р. А. Введение в науку о языке: Учебное пособие. М.: Добросвет-2000, 2003. 544 с. [Budagov R. A. Vvedeniye $v$ nauku o yazyke: Uchebnoye posobiye [Budagov R.A. Introduction to the science of language: Textbook]. M.: Dobrosvet-2000, 2003. 544 p. (In Rus.)]

Владимирцов 1989 - Владимирияов Б. Я. Сравнительная грамматика монгольского наречия. Введение и фонетика. 2-е изд. М.: Наука; ГРВЛ, 1989. 449 с. [Vladimirtsov В. Yа. Sravnitel'naya grammatika mongol'skogo narechiya. Vvedenie i fonetika [A comparative grammar of Mongolic dialects: introduction and phonetics]. 2nd ed. Moscow: Nauka, 1989. 449 p. (In Rus.)]

ГКЯ 1983 - Грамматика калмыцкого языка. Фонетика и морфология. Элиста: Калм. кн. изд-во, 1983. 335 с. [Grammatika kalmytskogo yazyka. Fonetika $i$ morfologiya [Kalmyk grammar: phonetics and morphology]. Elista: Kalm. Book Publ., 1983. 335 p. (In Rus.)]

Дыбо 2015 - Дьюо А. В. Названия оружия: от праалтайского к монгольскому // Российско-монгольский лингвистический сборник / под ред. Г. Ц. Пюрбеева. М.: Институт языкознания РАН; изд-во «Канцлер», 2015. C. 209-254. [Dybo A. V. Armour terms: from proto-Altaian to Mongolian ones. Rossiyskomongol'skiy lingvisticheskiy sbornik. G. Ts. Pyurbeev (ed.). Moscow: Institute of Linguistics of RAS; Kanzler Press, 2015. Pp. 209-254. (In Rus.)]

Кичиков 1997 - Кичиков А. Ш. Героический эпос «Джангар». Сравнительно-типологическое исследование памятника. Изд. 3-е. М.: Вост. лит., 1997. 320 с. [Kichikov A. Sh. Geroicheskiy epos «Dzhangar». Sravnitel'notipologicheskoe issledovanie pamyatnika [The heroic epic of Jangar: a comparative and typological study]. 3rd ed. Moscow: Vost. Lit., 1997. 320 p. (In Rus.)].

Кичиков 2017 - Кичиков А. Ш. Үгин туск үг (Слово о словах). На калм. яз. подг. текстов, сост., ред. Б. А. Кичиковой. Изд. 2-е, расшир. и перераб. Элиста: ЗАОр «НПП «Джангар», 2017. 160 c. [Kichikov A. Sh. Ügin tusk üg [A Word about Words]. B. A. Kichikova (comp., ed., etc.). 2nd ed., rev. and suppl. Elista: Dzhangar, 2017. 160 p. (In Kalm.)] 
КРС 1911 - Позднеев А. М. Калмыцко-русский словарь в пособие к изучению русского языка в калмыцких начальных школах. СПб. Тип. Имп. Акад. наук, 1911. 312 с. [Pozdneev A. M. Kalmytsko-russkiy slovar' v posobie $k$ izucheniyu russkogo yazyka $v$ kalmytskikh nachal'nykh shkolakh [Kalmyk-Russian dictionary: a supplement to the Russianlanguage learning book for Kalmyk elementary schools]. St. Petersburg: Imper. Acad. of Sc., 1911. 312 p. (In Kalm. and Rus.)]

КРС 1977 - Калмыцко-русский словарь / под ред. Б. Д. Муниева. М.: Русский язык, 1977. 768 c. [Kalmytsko-russkiy slovar' [KalmykRussian dictionary]. B. D. Muniev (ed.). Moscow: Russkiy Yazyk, 1977. 768 p. (In Kalm. and Rus.)]

Куканова 2016а - Куканова В. В. Опыт реконструкции значений лексических единиц, употребляющихся в эпосе «Джангар» // Монголоведение: сб. науч. тр. Вып. 8. Элиста: КалмНЦ РАН, 2016а. С. 184-198. [Kukanova V.V.An experimenton reconstruction of the meanings of the lexical items applied in the Jangar epic. Mongolovedenie. Is. 8. Elista: Kalmyk Scientific Center of RAS, 2016a. Pp. 184-198. (In Rus.)]

Куканова 2016 - Куканова В. В. Опыт реконструкции значений лексических единиц, употребляющихся в эпосе «Джангар» // Вестник калмыцкого института гуманитарных исследований РАН. Элиста: КалмНЦ PAH, 2016б. C. 121-130. [Kukanova V. V. An experiment on reconstruction of the meanings of the lexical items applied in the Jangar epic. Vestnik kalmytskogo instituta gumanitarnykh issledovaniy RAN. Elista: Kalmyk Scientific Center of RAS, 2016b. Pp. 121-130. (In Rus.)]

МРC 1893-1895 - Голстунский К. Ф. Монгольско-русский словарь. В 3-х т.: Т. І. СПб., 1895, 268 с.; Т. ІІ. СПб., 1894, 462 с.; Т. III. СПб., 1893. 491 c. [Golstunsky K. F. Mongol'sko-russkiy slovar' [MongolianRussian dictionary]. In 3 vol. St. Petersburg, 1893-1895. Vol. 1, 268 p.; vol. 2, 462 p.; vol. 3, 491 p. (In Mong. and Rus.)]

МРФС 1844-1846 - Ковалевский О. М. Монгольско-русско-французский словарь. В 3-х т.: T. I. Казань, 1844. С. 1-594; Т. II. Казань, 1846. С. 595-1545; Т. III. Казань, 1844. С. 1546-2690. [Kovalevsky O. M. Mongol'skorussko-frantsuzskiy slovar' [MongolianRussian-French dictionary]. In 3 vol. Kazan, 1844-1846. Vol. 1, pp. 1-594; vol. 2, pp. 5951545; vol. 3, pp. 1546-2690. (In Mong., French and Rus.)]
НККЯ - Национальный корпус калмыцкого языка (НККЯ) [электронный ресурс] // URL: http:kalmcorpora.ru (дата обращения: 12.04.2018). [Natsional'nyy korpus kalmytskogo yazyka (NKKYA) [Kalmyk National Corpus]. An Internet resource: see hyperlink above (accessed: 12 April 2018). (In Rus.)]

ОЛИЭД 1976 - Тодаева Б. Х. Опыт лингвистического исследования эпоса «Джангар». Элиста: Калм. кн. изд-во, 1976. 530 с. [Todaeva B. Kh. Opyt lingvisticheskogo issledovaniya eposa «Dzhangar» [The epic of Jangar: an effort of linguistic research]. Elista: Kalm. Book Publ., 1976. 530 p. (In Rus.)]

ОМС 2006 - Галзан Адьян. Өөрд-моңһл толь (Ойрат-монгольский словарь). Карамай. 1-4 т. 2006. 2011 c. [Galzan Ad'yan. Öördmoy $\gamma l$ tol' [Oirat-Mongolian dictionary]. Karamay. Vol. 1-4. 2006. 2011 p. (In Mong.)]

Пюрбеев 2011 - Пюрбеев Г. Ц. Военная терминология на материале монголо-ойратских памятников права XVII-XVIII вв. // Мат-лы Междунар. науч. конф. «Единая Калмыкия в единой России: через века в будущее», посв. 400-летию добровольного вхождения калмыцкого народа в состав Российского государства. Ч. 2. Элиста, 2011. С. 283-285. [Pyurbeev G. Ts. Military terms: a case study of the 17th-18th cc. Mongol-Oirat codes of laws. "Edinaya Kalmykiya v edinoy Rossii: cherez veka v buduschee» ['United Kalmykia in United Russia']. Proc. of the Conf. celebrating the 400th Anniversary of Kalmykia's voluntary joining the Russian State. Part 2. Elista, 2011. Pp. 283-285. (In Rus.)]

Пюрбеев 2015 - Пюрбеев Г. Ц. Эпос «Джангар»: культура и язык. Изд. 2-е, перераб. Элиста: 3АОр «НПП «Джангар», 2015. 280 c. [Pyurbeev G. Ts. Epos «Dzhangar»: kul'tura i yazyk [The epic of Jangar: culture and language]. 2nd ed., rev. Elista: Dzhangar, 2015. 280 p. (In Rus.)]

СЯОС 2001 - Тодаева Б. Х. Словарь языка ойратов Синьцзяна (По версиям песен «Джангар» и полевым записям автора / отв. ред. Г. Ц. Пюрбеев). Элиста: Калм. кн. изд-во, 2001. 494 c. [Todaeva B. Kh. Slovar'yazyka oyratov Sin'tszyana (Po versiyam pesen «Dzhangar» $i$ polevym zapisyam avtora [Xinjiang Oirats: a dictionary of their language (a case study of Jangar epic songs and collected field data)]. G. Ts. Pyurbeev (ed.). Elista: Kalm. Book Publ., 2001. 494 p. (In Rus.)]

ТСТБК 2016 - Цэндээ Ю., Пюрбеев Г. Ц. Монголын ойрад ба халимагийн уламжлалт ахуйн тайлбар толь.Улаанбаатар: Ганпринт, 
2016. 336 х. (Толковый словарь традиционного быта ойратов Монголии и калмыков. Улан-Батор: Ганпринт, 2016. 336 с.) [Tsendee Yu., Pyurbeev G. Ts. Mongolyn oyrad ba khalimagiyn ulamzhlalt akhuyn taylbar tol' [Traditional household activities of Kalmyks and Mongolia's Oirats: an explanatory dictionary].Ulaanbaatar: Ganprint, 2016.336 p. (In Mong.)]

Тувинские героические сказания 1997 - Тувинские героические сказания. Хунан-Кара. Боктуг-Кириш, Боро-Шэлэй / сост., вступ. ст., подгот. текста, подстр. пер., коммент. и словари С. М. Орус-оол; подгот. тувинских текстов под ред. Д. А. Монгуш; пер., коммент. к пер. А. В. Кудиярова. Новосибирск: Наука, 1997. 584 с. (Памятники народов Сибири и Дальнего Востока. Т. 12.) [Tuvinskie geroicheskie skazaniya. Khunan-Kara.
Boktug-Kirish, Boro-Sheley [Tuvan heroic tales. Khunan-Kara. Boktug-Kirish, BoroSheley]. S. M. Orus-ool (comp., prep., etc.); D. A. Mongush (ed.); A. V. Kudiyarov (transl., comment.). Novosibirsk: Nauka, 1997. 584 p. (In Tuv. and Rus.)]

ХРС 1953 - Хакасско-русский словарь под ред. Н. А. Баскакова. М.: Главиздат, 1953. 358 с. [Khakassko-russkiy slovar' [Khakass-Russian dictionary]. N. A. Baskakov (ed.). Moscow: Glavizdat, 1953. 358 p. (In Khak. and Rus.)]

Эрдниев 1985 - Эрдниев У. Э. Калмыки: Историко-этнографические очерки. 3-е изд., перераб. и доп. Элиста: Калм. кн. изд-во. 1985. 282 с., ил. [Erdniev U. E. Kalmyki: Istorikoetnograficheskie ocherki [The Kalmyks: historical and ethnographic essays]. 3rd ed., rev. and suppl. Elista: Kalm. Book Publ., 1985. 282 p. (In Rus.)] 


\title{
Revisiting the Problematic Semantics of Some Lexical Units to Denote Whips (a Case Study of the Jangar Epic)
}

Evgeniy V. Bembeev ${ }^{1}$

${ }^{1}$ Ph.D. in Philology (Cand. of Philological Sc.), Senior Research Associate, Department of Mongolian Philology, Kalmyk Scientific Center of the RAS (8, I. K. Ilishkin Str., Elista, 358000, Russian Federation). ORCID: 0000-0001-9936-221X. E-mail: galdma@yandex.ru

\begin{abstract}
Introduction: Analysis of semantic word structures, revelation and restoration of its meaning in an epic text is quite a difficult task aggravated by chronological non-homogeneity of different versions of the epic, loss or obscurity of semantics of a word, its conversion to passive vocabulary and some structural changes.

Goals: The paper aims to semantically analyze structures of lexemes that denote weapons (тоориц/товриц, елдң) in the heroic epic of Jangar.

Methods: The automatic analysis of texts makes it possible to operate large quantities of data, and it is the contextual method that comes to the forefront as a basic means to calculate some typical compatibility patterns for each lexical unit. Besides, analysis of dictionary entries coupled with valence analysis reveal peculiarities of semantic definitions in lexicographic sources, grammatical and accentual features of sought-for units.

Results: The study has not only revealed and restored the meaning of a separate lexeme but also - in some places - identified semantic differences within the same lexeme. The differences are determined by differing contexts of use that — in their turn — result from stadial peculiarities of a certain version of the epic, distinct features of the taleteller's performance tradition, and chronological periods when the oral epic text was recorded.

Conclusions: The right use (meaning) of the word товрцг is 'a whip (scourge) with a reinforced tip and a plaiting pattern resembling that of a closed pine-cone', i.e., 'a combat whip (scourge)'. The word belongs to a common Turko-Mongolic vocabulary of the peoples inhabiting (originating from) the Sayan-Altai highlands. The form moopų (traced twice in texts recorded from D. Shavaliev) can also be viewed as the author's novelty or a distortion. Still, the form could have appeared as a misspelling during a recording of the oral text.

The lexemе елдң is widely (52 times) met in different versions and contexts of the epic. Its meanings vary depending upon stadial (chronological) affiliations of the version and areas the performance traditions came from. Within the epic text the word елдң is used in denotative and connotative meanings thus giving rise to quite a semantic spectrum: 1) 'nagaika' as a whip — маля; 2) 'bodyguard', 'defender'; 3) 'noble, idle'; 4) 'irrepressible', 'fidgety', 'restless', 'fussy'. So, in the early Baya Dorbet version the lexemе елдң manifests the meanings as follows: 1) 'nagaika' as a whip - маля; 2) елдң is widely used as 'hero', specifically as 'nagaika-bearer'. In meaning 3, the word is contextually translated as 'noble, celebrating' to depict Jangar Bogdo, the main character, to whom his knights (warriors) arrive to celebrate Tsayan Sar. In meaning 4, 'irrepressible' елдң serves to describe the popular epic hero Khongor and underline his violence and impetuosity.

In later versions of the epic a semantic spectrum of the word елдң contains semes as follows: 1) 'nagaika' as a whip - маля; 2) not used; 3) not used; 4) in a connotative meaning it is used to negatively characterize a 'self-willed, restless' individual. Consequently, the semantic spectrum of the lexemе елдң grows narrower and poorer — on its way from the early Baya Dorbet version of the epic towards post-classical ones.
\end{abstract}

Keywords: Kalmyk language, epic of Jangar, explanatory dictionary, whip, scourge, meanings, lexeme, semantics, corpus 